УДК 378.016:61:577.1]-057.875

DOI 10.11603/2411-1597.2021.3.12644

\title{
КОНЦЕПЦІЯ ВИКЛАДАННЯ ДИСЦИПЛІНИ «МЕДИЧНА ТА БІООРГАНІЧНА ХІМІЯ» СТУДЕНТАМ ЗІ СПЕЦІАЛЬНОСТІ «МЕДСЕСТРИНСТВО»
}

\author{
Г. О. Сирова, О. О. Завада, В. О. Макаров
}

\section{Харківський національний медичний університет}

\begin{abstract}
У статті розглянуто основні напрямки оптимізації самостійної роботи студентів під час вивчення дисципліни «Медична та біоорганічна хімія» студентам зі спеціальності «Медсестринство». Метою дослідження стало вивчення сучасних тенденцій в галузі охорони здоров'я, які моделюють майбутнє сестринської справи, та формування концепції викладання фундаментальної дисципліни «Медична та біоорганічна хімія» як підгрунтя при вивченні фахових предметів.
\end{abstract}

\section{THE CONCEPT OF TEACHING THE DISCIPLINE “MEDICAL AND BIOORGANIC CHEMISTRY” TO STUDENTS IN THE SPECIALITY “NURSING”}

\author{
H. O. Syrova, O. O. Zavada, V. O. Makarov
}

Kharkiv National Medical University

\begin{abstract}
The article considers the main directions of optimization of independent work of students during the study of the discipline of "Medical and bioorganic chemistry" for students majoring in "Nursing". The aim of the study was to study current trends in health care, which model the future of nursing, and to form the concept of teaching fundamental disciplines such as "Medical and bioorganic chemistry" as a basis for the study of professional subjects.
\end{abstract}

Вступ. Загальновідомим є визначення терміну «здоров'я», який зазначений у статуті Всесвітньої організації охорони здоров'я: «Здоров'я - стан повного фізичного, психологічного і соціального благополуччя, а не тільки відсутність хвороб або фізичних дефектів». Тому актуальним питанням розвитку системи охорони здоров'я $\epsilon$ збереження здоров'я нації в цілому та кожної окремої людини. У зв'язку з цим, значною мірою має велике значення рівень професійної підготовки середнього медичного персоналу, а саме медичних сестер як найбільшої частки кадрового ресурсу.

Огляд наукової літератури показав, що медичні сестри - одна з найбільших професійних груп у будь-якій країні, їх професійна діяльність впливає на розвиток будь-якого суспільства, тому професійне вдосконалення медичних сестер буде сприяти формуванню культури професійного середовища в цілому. Значення медичної сестри дуже точно розкриває вислів однієї із засновниць сестринської справи як професії, яка була революціонером у своїй справі, - Вірджинії Хендерсон: «Медсестра - це ноги безногого, очі сліпого, опора дитині, джерело знання та впевненості молодої матері, вуста тих, хто надто слабкий чи занурений в себе, щоб казати».

Сучасна термінологія щодо «сестринської справи» дещо змінилась, Міжнародна рада медичних сестер (International Council of Nurses (ICN)) найбільш широко розкриває вимоги до професійних компетенцій медичних сестер. За визначенням ICN, медична сестра займається у своїй трудовій діяльності «індивідуальним і спільним доглядом за особами різного віку, сімей, груп і співтовариств, хворими або здоровими в будь-яких умовах. Складові частини сестринського догляду: пропаганда здорового способу життя, профілактика хвороб, догляд за хворими, інвалідами та вмираючими. Крім того, медичні сестри відіграють ключову роль в підтримці та пропаганді безпеки навколишнього середовища, дослідженнях, беруть участь у формуванні політики охорони здоров'я, управлінні системами охорони здоров'я, стаціонарної допомоги та освіти».

(с) Г. О. Сирова, О. О. Завада, В. О. Макаров, 2021

24 ISSN 2411-1597. МЕДСЕСТРИНСТВО. 2021. № 3 
Виходячи з цього, актуальним постає питання перегляду концепцій навчання майбутніх медичних сестер та оптимізація навчальних програм із базових дисциплін, а саме «Медичної та біоорганічної хімії».

Мета дослідження: моніторинг сучасних тенденцій в галузі охорони здоров'я, які моделюють майбутнє сестринської справи, дослідження актуальних питань в освіті медичних сестер, зокрема викладання фундаментальної дисципліни «Медична та біоорганічна хімія» як підґрунтя при вивченні фахових предметів.

Основна частина. Виходячи з положень Закону України «Про вищу освіту», вища школа України повинна забезпечити підготовку фахівців, які будуть готові до роботи в умовах світових стандартів. Такий підхід вимагає модернізації та розвитку системи фахової професійної освіти.

Одним з головних завдань дисципліни «Медична та біоорганічна хімія», яку викладають у Харківському національному медичному університеті студентам зі спеціальності «Медсестринство» на першому та третьому курсах, $\epsilon$ підготовка студентів до освоєння матеріалу з профільних дисциплін, а також навчання студентів самостійно опрацьовувати навчальний матеріал. Як відомо, важливим моментом у формуванні особистості студента $\epsilon$ розвиток його творчого потенціалу та індивідуальних здібностей. Самостійна робота найкраще сприяє формуванню зазначених навичок. Самостійний пошук інформації з метою розв'язання поставленого завдання змушує студентів думати, міркувати, вникати в питання, аналізувати його, при цьому використовувати різні форми і методи, в тому числі пошукові й дослідницькі, важливим також $є$ формування у студентів навичок користування комп'ютерними програмами. У результаті досягається основна мета роботи - сприйняття матеріалу, його запам'ятовування, навчання роботі з додатковими джерелами, в тому числі на електронних носіях. Педагогічна майстерність полягає саме в тому, щоб розвинути у студентів вміння самостійно отримувати знання, найкраще це можна досягти шляхом залучення їх в активну діяльність на всіх етапах навчання.

Викладання дисципліни «Медична та біоорганічна хімія» студентам, які навчаються за спеціальністю «Медсестринство», вимагає максимально візуально аргументованого викладання матеріалу. Практичні заняття побудовані таким чином, що під час розглядання теоретичних питань використовують моделі молекул, мультфільми тощо. На кожному лабораторно-практичному занятті студенти спочатку дивляться фільм на тему лабораторної роботи, обговорюють її проведення, лише потім виконують лабораторну роботу, це також допомагає краще засвоїти матеріал та більш детально розглянути тему заняття $[1,2]$.

У процесі навчання враховуємо роль медичної сестри в системі охорони здоров'я: ми розуміємо, що це фахівець, який повинен мати певний обсяг знань 3 хімії - без чого неможливо досконале розуміння фізіологічних процесів, роботи з лікарськими препаратами, тому завжди використовуємо міждисциплінарну інтеграцію.

Для якісного оволодіння матеріалом з курсу «Медична та біоорганічна хімія» важливою $є$ самостійна робота студентів, на неї відводять певний час за програмою. Самостійна робота на кафедрі медичної та біоорганічної хімії має різні форми $[3,4]$. Починається самостійна робота на лекціях, на яких педагоги пояснюють основні теоретичні питання, а деякі виносять на самостійне опрацювання студентам із подальшим обговоренням. Потім при підготовці до лабораторно-практичних занять студенти користуються методичними рекомендаціями до кожного заняття та навчально-методичним комплексом. Структура даних матеріалів побудована таким чином: актуальність теми, зміст теми у вигляді графлогічної схеми, перелік конкретних цілей та базових знань і навичок, які необхідні для засвоєння теми, перелік теоретичних питань до заняття з поясненнями, практичні роботи, які виконують на занятті, в тому числі лабораторні, приклади завдань для самоконтролю.

На самостійне опрацювання студентам запропоновано п'ять навчальних тем, таких як: 1) інтерпретація закономірностей та пояснення механізмів фізико-хімічних процесів, що відбуваються в розчинах на межі поділу фаз, аналіз взаємозв'язків між явищами та їх біологічною значущістю і використанням у практичній медицині; 2) пояснення принципів певних методів кількісних визначень біологічноактивних речовин; 3) класифікація хімічних реакцій; 4) теоретичні аспекти біоорганічної хімії; 5) структура та біологічні функції гетероциклічних сполук.

3 метою оптимізації рівня організації самостійної роботи студентів у навчальний процес ми використовуємо такі методичні прийоми: формування 
у студентів інтересу до самостійної роботи (вхідний контроль: тестовий контроль самостійно засвоєних знань на початку заняття, який впливає на сумарну оцінку з заняття); розробка необхідного навчальнометодичного матеріалу для організації самостійної роботи студентів; постійний контроль самостійної роботи студентів та допомога студентам при усуненні недоліків, пояснення незрозумілих моментів з теми, яку розглядають, та інші. Колектив кафедри розпочав роботу зі створення дистанційного курсу з дисципліни «Медична та біоорганічна хімія» для студентів зі спеціальності «Медсестринство».

\section{СПИСОК ЛІТЕРАТУРИ}

1. Аудиторна самостійна робота студентів як інструмент формування гармонізованої особистості / Г. О. Сирова, В. О. Макаров, В. М. Петюніна та ін. // Сучасні концепції викладання природничих дисциплін в медичних освітніх закладах (біологія, фізика, хімія, педагогіка, психологія) : матеріали X Міжрегіональної науково-методичної інтернет-конференції, 5-6 грудня 2017 р. - Харків, 2017. C. 56-58.

2. Самостійна робота студентів на заняттях «Медичної хімії» / Г. О. Сирова, В. О. Макаров, Л. В. Лук'янова та ін. // Сучасні концепції викладання природничих дисциплін в медичних освітніх закладах (біологія, фізика, хімія, педагогіка, психологія) : матеріали X Міжрегіональної науково-методичної інтернет-конференції, 5-6 грудня 2017 р. - Харків, 2017. - С. 104-105.
Висновки. Одним із важливих напрямків у концепції викладання дисципліни «Медична та біоорганічна хімія» студентам зі спеціальності «Медсестринство» $\epsilon$ комплексна організація самостійної роботи студентів та ії оптимізація. У цілях оптимізації викладання дисципліни «Медична та біоорганічна хімія» для студентів зі спеціальності «Медсестринство» доцільним $\epsilon$ створення курсу на платформі Moodle 3 використанням сучасної навчально-методичної літератури, відеофільмів та очних матеріалів.

3. Самостійна робота студентів при створенні симуляційних моделей / Г. О. Сирова, В. О. Макаров, О. О. Завада та ін. // Інновації у вищій медичній та фармацевтичній освіті України (з дистанційним під'єднанням ВМ(Ф)НЗ України за допомогою відеоконференц-зв'язку) : матеріали XVI Всеукраїнської науково-практичної конференції 3 міжнародною участю, м. Тернопіль, 16-17 травня 2019 р. - Тернопіль, 2019. - С. 309-310.

4. Особливості викладання біологічної хімії на медикопсихологічному факультеті Національного медичного університету імені О. О. Богомольця / І. В. Ніженковська, Л. В. Яніцька, О. В. Стеченко та ін. // Медична освіта. 2012. - № 3. - С. 66-68. 